\title{
Simulation-based modeling of building complexes construction management
}

\author{
Aleksandr Shepelev ${ }^{1, *}$, Galina Severova ${ }^{1}$ and Irina Potashova ${ }^{2}$ \\ ${ }^{1}$ Northern (Arctic) Federal University named after M.V. Lomonosov, Department of Construction, \\ 163002 Northern Dvina Embankment, 17, Arkhangelsk, Russia \\ ${ }^{2}$ Sochi State University, Departmen of Finance, credit and world economy chair, 354000, Sovetskaya \\ St., 26A, Sochi, Russia
}

\begin{abstract}
The study reported here examines the experience in the development and implementation of business simulation games based on network planning and management of high-rise construction. Appropriate network models of different types and levels of detail have been developed; a simulation model including 51 blocks (11 stages combined in 4 units) is proposed.
\end{abstract}

\section{Introduction}

In modern conditions great interest for all participants in the town-planning process is represented by effective methods of organizing and producing works for the construction of buildings of different types and floors, especially high-rise residential and multifunctional buildings and complexes built with the use of advanced technologies [1-3]. We have accumulated sufficient experience in erecting high-rise buildings and complexes in Moscow, St. Petersburg and a number of regional centres of Russia $[4,5]$. As the domestic and world practice shows, an increase in the volume of such construction is inevitable.

At the same time, the existing federal state standards of higher education require a very high level of competencies of future construction managers: specialists whose major is "Construction of unique buildings and structures" and graduates holding a bachelor or a master degree and majoring in Construction. Achievement of these requirements is largely facilitated by business simulation games, as evidenced by the research of a number of universities and institutes [3,6], including more than 35 years of experience in the department of construction at Northern (Arctic) Federal University (NArFU, formerly ALTI-ASTU) [7, 8].

The business simulation game (SG) "Network Planning and Construction Management of a Complex" (NPCMC), developed at the Department of Economics and Organization of Construction of the Kiev Civil Engineering Institute under the guidance of Professor V.I. Rybal'skiy, has become one of the most widely used in our country games for the training of civil engineers in recent decades. It is based on simulation of planning and management of the on-line construction of complexes of similar industrial buildings. The development of new modifications of SG "Network" and "Network-2" [7, 8] was the result of extensive and

* Corresponding author: a.shepelev@narfu.ru 
creative use and improvement of this SG in NArFU. Many years of experience and research have shown that one of the main advantages of business games is that they simulate situations that can arise (and they do arise) on real construction sites, solutions for emerging problems can be considered in advance, a team successfully trained for advanced methods of planning and management being formed [6-8].

Thus, it follows from the above that it is timely, relevant and objectively useful to develop a version of the business game based on the existing ones, which contributes to the improvement of the training of students majoring in Construction in the field of organization, planning and management of construction production and is based on network modeling of high-rise buildings complexes erection.

\section{Development of network models for construction of high-rise buildings}

It is known that the relevant organizational and technological documentation (OTD) of various temporal and hierarchical levels is being developed. At the same time, the theory and practice of the construction industry $[1,2,4,9]$ show that one of the most important elements in the OTD are calendar plans for construction (production of works) that are developed and displayed on the basis of various organizational and technological models. Network models (NM) of various types are the most effective tool for solving scheduling problems at different stages of preparation and subsequent construction management $[1,4]$.

At the same time, a variety of design solutions for buildings (including high-rise buildings), contractor and subcontracting construction and assembly organizations, situations and organizational and technological conditions and solutions, the possibilities for combining the stages of construction and types of work lead to the need for a "typical" modeling of the construction of facilities.

Based on experience in planning of works organization and long-term studies carried out at the Department of Construction Production and summarized in [9], a system of generalized deterministic time-based NM (conventional NMs have been known since the 1970s) reflecting the real relationships between construction works in more detail was proposed as the main tool for the development of calendar plans at various levels.

As an example, Figure 1 shows an enlarged network model for the construction of a highrise residential or multi-functional building (for a combined method of organizing work). It has 15 enlarged works: 1 - Preparatory works; 2 - Excavation of a foundation pit; 3 - Laying the foundations; 4 - Construction of the underground part of the building; 5 - Waterproofing, backfilling; 6 - Erection of the elevated part of the building; 7 - Roof installation; 8 - Special works, 1 cycle; 9 - Plastering and cladding works; 10 - Carpentry and painting, 1 cycle; 11 Special works, 2 cycle; 12 - Carpentry and painting, 2 cycle; 13 - Installation of external networks; 14 - Landscaping, gardening and small forms; 15 - Preparation for facility commissioning.

This model uses elements of generalized network models - front links of the type "not earlier", allowing to take a variety of options for organizational and technological solutions for the construction of objects of this type (different number of floors, work volumes, labor, intensity and timing of work and stages, their terms, resource allocation, etc.) into account.

The available experience shows the possibility of successful implementation of such network models for scheduling the erection of buildings and complexes as part of construction projects, and with greater detail (up to 30-50 names of activities) - for the development of work schedules, operational planning and management of their construction.

At the same time, calendar plans for specific facilities, conditions and organizational and technological decisions are developed and displayed in the form of network graphs (respectively, enlarged or detailed) based on the simplest or multi-purpose deterministic 
temporary network models. They are used in the process of preparation and implementation of SG for the planning and operational management of the construction of buildings.

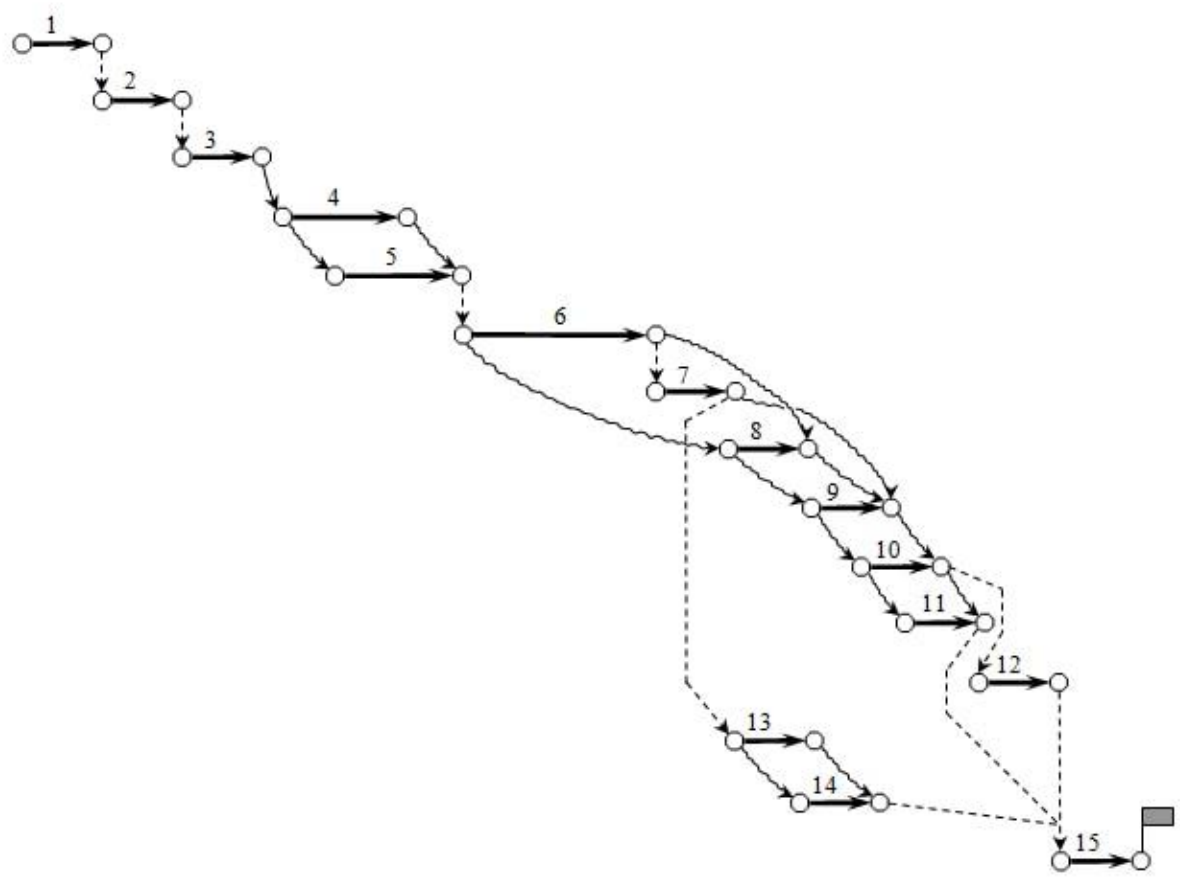

Fig. 1. A generalized network model for the construction of a high-rise building.

\section{Results of the modeling of the business game related to the organization of construction of the complex}

As a result of the long-term use and improvement of the SG for the organization and management of construction (NPCMC, "Network", etc.) [7, 8] we proposed a new modification of the SG - "Network-3". In the course of this SG, the functioning of the system of network planning and management (NPM) of the construction of a complex of buildings (including high-rise residential or multifunctional) is simulated. Multipurpose network models (developed on the basis of generalized network models) are used, rational use of resources is taken into account, and the main stages are "Initial planning" and "Operational management".

In view of the above, during the modeling of the SG "Network-3", developed, documented and successfully applied: the necessary input data, instructions to participants, forms and examples of documentation, reference and graphic materials. The block diagram of this SG includes 51 blocks in 11 stages, combined in 4 units. The enlarged model of the SG "Network-3" is presented in Table 1.

An important result of this SG was the students' awareness of the organizational and technological reliability of the decisions they made with the planned intensity of work and other conditions of construction that are affected by destabilizing factors arising in random combinations [10-12].

During the implementation of business games in the teaching and learning process, anonymous questioning of participants (students, teachers, representatives of construction organizations) was regularly conducted, the feedback questionnaires being developed by our department. 
Table 1. Model of simulation game "Network-3".

\begin{tabular}{|c|c|c|}
\hline SG stages & SG blocks & SG participants \\
\hline \multicolumn{3}{|c|}{ Unit 1. Preparation for the game } \\
\hline \multirow[t]{7}{*}{ 1. Preparation } & $\begin{array}{l}\text { 1.1. Making decision on what the complexes should } \\
\text { consist of and how inter-related their parts should be }\end{array}$ & $\begin{array}{l}\text { SG instructor (SGI), } \\
\text { arbitration (A) }\end{array}$ \\
\hline & $\begin{array}{l}\text { 1.2. Setting up the length of construction periods and } \\
\text { bonus accumulation }\end{array}$ & SGI, A \\
\hline & $\begin{array}{l}\text { 1.3. Election (appointment) of complexes managers, } \\
\text { release of construction documents and initial data }\end{array}$ & SGI, A \\
\hline & $\begin{array}{l}\text { 1.4. Appointment of NPM staff and executives }(\mathrm{E}) \text {, release } \\
\text { of construction documents and initial data }\end{array}$ & $\begin{array}{l}\text { Complexes managers } \\
(\mathrm{CM})\end{array}$ \\
\hline & 1.5. Reviewing of instructions and documents & $\mathrm{CM}$ \\
\hline & 1.6. Reviewing of instructions, documents and initial data & NPM staff (NPMS) \\
\hline & 1.7. Reviewing of instructions and initial data & $\mathrm{E}$ \\
\hline \multicolumn{3}{|c|}{ Unit 2. Initial planning of the construction of buildings and complexes } \\
\hline \multirow{2}{*}{$\begin{array}{l}\text { 2. Tasks } \\
\text { description } \\
\text { distribution }\end{array}$} & 2.1. Preparation and distribution of tasks description & SGI, A \\
\hline & 2.2. Development of construction execution strategy & $\mathrm{CM}$ \\
\hline \multirow[t]{4}{*}{$\begin{array}{l}\text { 3. Initial network } \\
\text { models } \\
\text { development }\end{array}$} & $\begin{array}{l}\text { 3.1. Development of tasks on initial network models } \\
\text { (INMs) development and distribution of work sheets for } \\
\text { them among the executives }\end{array}$ & NPMS \\
\hline & 3.2. Development of INMs and work sheets for them & $\mathrm{E}$ \\
\hline & 3.3. INMs and work sheets testing & NPMS \\
\hline & 3.4. INMs and work sheets testing control & $\mathrm{CM}$ \\
\hline \multirow{4}{*}{$\begin{array}{l}\text { 4. Development } \\
\text { and engineering } \\
\text { analysis of } \\
\text { complex network } \\
\text { models }\end{array}$} & 4.1. Development of complex network model (CNM) & NPMS \\
\hline & 4.2. Engineering analysis of time on CNM & NPMS \\
\hline & 4.3. CNM testing & $\mathrm{CM}$ \\
\hline & 4.4. CNM testing & SGI, A \\
\hline \multirow{7}{*}{$\begin{array}{l}\text { 5. Making CNM } \\
\text { parameters } \\
\text { consistent with } \\
\text { the set up lengths } \\
\text { of construction } \\
\text { periods }\end{array}$} & $\begin{array}{l}\text { 5.1. Engineering analysis evaluation, making proposals on } \\
\text { reduction of construction periods lengths }\end{array}$ & NPMS \\
\hline & $\begin{array}{l}\text { 5.2. Engineering analysis evaluation, preparation for } \\
\text { operational meeting }\end{array}$ & $\mathrm{CM}$ \\
\hline & $\begin{array}{l}\text { 5.3. Making proposals on reduction of construction periods } \\
\text { lengths }\end{array}$ & $\mathrm{E}$ \\
\hline & $\begin{array}{l}\text { 5.4. Participation in the meeting, correction of parameters } \\
\text { due to decisions made at the meeting }\end{array}$ & E, NPMS \\
\hline & 5.5. Participation in the meeting, coordination of proposals & $\mathrm{CM}$ \\
\hline & 5.6. Monitoring of the conduct of the meeting & SGI, A \\
\hline & 5.7. Correction and recalculation of CNM & NPMS \\
\hline \multirow{6}{*}{$\begin{array}{l}\text { 6. CNM approval } \\
\text { and analysis of } \\
\text { initial planning } \\
\text { results }\end{array}$} & 6.1. Making proposals on approval of redeveloped CNMs & NPMS, CM \\
\hline & 6.2. CNM approval and/or correction of time restrictions & SGI, A \\
\hline & 6.3. Scoring & $\mathrm{E}$ \\
\hline & 6.4. Scoring and monitoring of executives & NPMS \\
\hline & 6.5. Scoring and monitoring of NPMS & $\mathrm{CM}$ \\
\hline & 6.6. Monitoring the CNM and scoring & SGI, A \\
\hline \multicolumn{3}{|c|}{ Unit 3. Operational management of construction works (3 cycles) } \\
\hline \multirow{2}{*}{$\begin{array}{l}\text { 7. Obtaining } \\
\text { operational data } \\
\text { about the } \\
\text { condition of } \\
\text { complexes and its } \\
\text { processing }\end{array}$} & $\begin{array}{l}\text { 7.1. Delivering information about the time of obtaining } \\
\text { data and changing of set up construction periods }\end{array}$ & SGI, A \\
\hline & $\begin{array}{l}\text { 7.2. Processing of data on the performance of construction } \\
\text { works and adjustment of estimation of coming period }\end{array}$ & $\mathrm{E}$ \\
\hline \multirow[t]{2}{*}{$\begin{array}{l}8 . \text { Renewal of } \\
\text { models, data } \\
\text { processing and }\end{array}$} & $\begin{array}{l}\text { 8.1. Analysis of input operational information; fixation of } \\
\text { construction works performance on CNM; data processing } \\
\text { and CNM (re)calculation }\end{array}$ & NPMS \\
\hline & 8.2. (Re)calculation of CNM of complex (stage) & NPMS \\
\hline
\end{tabular}




\begin{tabular}{|c|c|c|}
\hline \multirow{2}{*}{$\begin{array}{l}\text { CNM } \\
\text { (re)calculation }\end{array}$} & 8.3. CNM (re)calculation monitoring & $\mathrm{CM}$ \\
\hline & $\begin{array}{l}\text { 8.4. Construction works performance evaluation and } \\
\text { disclosure of delays }\end{array}$ & NPMS \\
\hline \multirow{6}{*}{$\begin{array}{l}\text { 9. Factual report } \\
\text { on condition of } \\
\text { complexes and } \\
\text { optimization of } \\
\text { CNM parameters }\end{array}$} & 9.1. Making proposals on reduction of work of executives & CM, NPMS \\
\hline & 9.2. Making proposals on elimination of delays & $\mathrm{E}$ \\
\hline & $\begin{array}{l}\text { 9.3. Participation in the meeting; correction of parameters } \\
\text { due to decisions made at the meeting }\end{array}$ & E, NPMS \\
\hline & $\begin{array}{l}\text { 9.4. Discussion and making decisions on further } \\
\text { performance of construction works }\end{array}$ & $\mathrm{CM}$ \\
\hline & 9.5. Monitoring of the conduct of the meeting & SGI, A \\
\hline & 9.6. Correction and recalculation of CNM & NPMS \\
\hline \multirow{4}{*}{$\begin{array}{l}\text { 10. Analysis of } \\
\text { operational } \\
\text { management } \\
\text { cycle outcomes }\end{array}$} & 10.1. Scoring & $\mathrm{E}$ \\
\hline & 10.2. Scoring and monitoring of executives & NPMS \\
\hline & 10.3. Scoring and monitoring of NPMS & $\mathrm{CM}$ \\
\hline & 10.4. Monitoring of CNM and scoring & SGI, A \\
\hline \multicolumn{3}{|c|}{ Unit 4. Analysis and implications of simulation game results } \\
\hline \multirow[t]{5}{*}{$\begin{array}{l}\text { 11. Follow-up } \\
\text { activities }\end{array}$} & $\begin{array}{l}\text { 11.1. Final analysis of the conduct and outcomes of } \\
\text { performance, distribution of feedback questionnaires } \\
\text { among the SG participants }\end{array}$ & SGI, A, CM \\
\hline & $\begin{array}{l}\text { 11.2. Announcement of the results and analysis of the } \\
\text { conduct of the simulation game }\end{array}$ & SGI, A \\
\hline & 11.3. Completion of feedback questionnaires & CM, NPMS, E, A \\
\hline & $\begin{array}{l}\text { 11.4. Feedback questionnaires review; conclusions and } \\
\text { recommendations }\end{array}$ & SGI, A \\
\hline & 11.5. Awarding of winners & SGI \\
\hline
\end{tabular}

All participants noted the originality of this type of practical training, excitement, competition of units and complexes, the opportunity to make collective and independent decisions, efficiency for studying relevant disciplines - that is, the applicability and necessity of business games in the teaching and learning process, as well as in real planning and construction management.

In the process of conducting business games and based on their results, interesting and useful suggestions on the content of SG, improvement of criteria, scoring and forms of documentation, additional participants, etc. were received. The findings indicate good prospects for further development and improvement of simulation exercise in construction, the fact that game methods are an integrated part of education and belong to the best and most effective ways of training specialists.

\section{Results}

Based on the foregoing, it can be concluded that the goal of the work has been achieved and modeling of the construction of building complexes, including high-rise buildings, using technologies and methods of conducting business (management) games is quite effective and has good prospects.

\section{Conclusion}

To recapitulate the findings of the present research: preparation, improvement and modeling of the business simulation games make the teaching and learning process at universities' department of construction more effective. Business simulation games are applicable in real 
network planning and management of construction, including construction of high-rise buildings and complexes.

The research highlighted the need for further development in this field, aiming at expanding the scope of simulation games application and achieving greater adequacy of games, used in real construction activity.

\section{Acknowledgements}

The authors are grateful to all the teachers and students who have been participating in the preparation, implementation and improvement of business simulation games at the NArFU Construction Department for more than 35 years, as well as to the 6th year students majoring in "Construction of unique buildings and structures" for joint development of network models for the construction of a group of high-rise buildings in 2017.

\section{References}

1. L.V. Kievskiy, City development: Collection of research papers 2006-2014 (2014)

2. P.P. Oleynik, V.I. Brodskiy, Vestnik MGSU, 6, 119-125 (2012)

3. V.I. Rybal'skiy, Industr. and civil eng., 9, 8-11 (2003)

4. Temporary recommendations on technology and organization of construction of multifunctional high-rise buildings and building complexes in Moscow. MDC 1223.2006 (2006)

5. Recommendations on the construction of residential and public high-rise buildings. RMD 31-04-2008 St. Petersburg (2008)

6. S.A. Barkalov, V.F. Babkin, A.V. Shchepkin, Business simulation games in organization and management (2003)

7. A.N. Fedotov, A.L. Shepelev, V.I. Rakovskiy, Contribution of ASTU scientists to the development of science and technology: Collection of research papers, 232-239 (1999)

8. A.L. Shepelev, G.V. Severova, V.I. Rakovskiy, Theoretical foundations of construction: Collection of reports of the XIX Slovak-Polish-Russian seminar, 451-458 (2010)

9. A.L. Shepelev, Industr. and civil eng., 10, 41-44 (2012)

10. A.A. Gusakov, A.V. Ginzburg, S.A. Veremeenko, etc, Organizational and technological reliability of construction (1994)

11. S.E. Klimov, Methodology of scheduling of construction production in the harsh conditions of the Far North (2005)

12. K.C. Crandall, J. of the Constr. Division, 102, 415-423 (1976) 